Назаревич Вікторія

кандидат психологічних наук, доцент, доцент кафедри вікової та педагогічної психології, Рівненського державного гуманітарного університету http://orcid.org/ 0000-0002-0111-7070 DOI https://doi.org/10.35619/prap_rv.vi14.167

\title{
ФУНКЦІЇ ОСТРАКІЗМУ В ОСВІТНЬОМУ СЕРЕДОВИЩІ
}

Анотація. У статті автор здійснює спробу розкрити особливості функцій остракізму в системі умов сучасної освіти та систематизувати сочіально-психологічні прояви соціального відторгнення індивідів або груп. Особливу увагу приділено аналізові системи функціонального наповнення явища та його проявів в освітянському просторі, впливу на особистість відсутності уваги й визнання. Особи, які піддаються остракізму в освітніх закладах протягом тривалого часу, демонструють низький рівень психічного здоров'я.

Стаття присвячена критеріям аналізу основних стадій становлення групи та входження індивіда в систему освіти. Вказано на те, щуо особистість має потребу належати до групи, щоб вижити; унаслідок иього кожен індивід володіє підвищеними когнітивними здібностями для вияву сигналів про відмову в сочіальному прийнятті. Тож відмова або насторога з боку групи $\epsilon$ загрозливою ситуацією, щуо переживається як почуття особистої невпевненості та призводить до остракізації особи. Висвітлені фактичні умови протікання прочесу остракізації в освітньому середовищі, здійснено аналіз практичної сторони перебування індивідів в освітянському просторі й констатовано поділ його функцій на дві основні групи за характером дії. Вказано на роль розгляду проходження етапів особистісного становлення в межах академічної групи за загальноприйнятими науковими рамками становлення групи, які можуть характеризуватися: визначенням меж групи, розвитком нових навичок у їі членів, розвитком і визначенням відповідних групових ролей, генерацією планів та ідей, погодженням альтернатив сумісного існування, вирішенням конфліктів, впровадженням спільної діяльності й підтримкою єдності.

Зроблено висновки в системі функцій остракізму в освітянському просторі, шчо кожна група проходить етапи конфлікту, непорозумінь, неприйняття, відторгнення ідей $і$ окремих членів групи в процесі становлення. Це дає основу стверджувати: остракізація є невід 'ємним елементом входження і становлення індивідів в освітньому середовищі.

Ключові слова: остракізм, остакізатор, соціальне неприйняття, функціональність остракізму, освітнє середовище, групоутворення, конфлікт.

Постановка проблеми. Суспільство відкидало проблему остракізму і визначало це явище як зневажливу соціальну поведінку до 80 -х років XX століття. Відтоді було проведено експериментальні дослідження і огляд показників зазначеного явища, докладно описано негативні ефекти, викликані навіть незначним виключенням індивідів. Такий стан вивчення проблеми призвів до втручання політики та привернення інституційної і державної уваги, що уможливлює визначення вивчення цього явища як загальнодержавного, з метою профілактики інтолерантних проявів.

Остракізм заподіює більшу шкоду виключеному індивіду, ніж процес булінгу, але оскільки він характеризується відсутністю уваги і визнання, його важко контролювати й регулювати. Особи, які піддаються остракізму в освітніх закладах протягом тривалого часу, демонструють низький рівень психічного здоров'я. Підлітки та діти молодшого шкільного віку є більш схильними до впливу відторгнення однолітків і думок однолітків, ніж дорослі. Серед дітей та підлітків остракізм може впливати на когнітивні здібності, перешкоджати фізичній активності й стимулювати прийом їжі в індивідів 3 надмірною вагою. Важливою причиною вивчення зазначеної теми $є$ чітка кореляція остракізації 3 наявністю у виключених осіб хронічних захворювань (наприклад, spina bifida) та особливих психофізіологічних особливостей зокрема 
аутизму. А також з формуванням таких явищ, як ксенефобія та гандикапізм. Освітнє середовище, за Collins, визначається як «наближене до цілого інституту», в якому діяльність індивідів характеризують частими взаємодіями 3 іншими, необхідністю участі в цій взаємодії та підпорядкування ієрархічній структурі, яка впливає на статус особи в установі. У більшості досліджень, присвячених остракізації в освітньому середовищі, використовують термін «залякування». Залякування - це тип психологічного насильства, для якого характерні, зокрема, повторення й асиметричні владні відносини. Остракізм $є$ особливим випадком залякування та належить до категорії відносного залякування або проявляється у формі ігнорування. Відносне залякування визначають як акти поширення зловмисних чуток, виключення 3 соціальної діяльності, веббулінг, мобінг та ін. Тому деталізація та науково осмислення даного явища $\epsilon$ особливо потрібним.

Соціальна ізоляція, виключення й ігнорування інших $є$ основною складовою знущань в школі. Комплексне дослідження в США показало, що 13\% дітей страждають від фізичного насильства, 26\% - від ізоляції, соціальної ізоляції або ігнорування, а 32\% - від поширення чуток про них. Щодо системи професійної освіти дані відсутні.

Аналіз останніх досліджень 3 проблеми. Остракізм визначають як агресивну соціальну поведінку (Gruter, Masters 1986; Williams 2001), і значну увагу приділяють вивченню негативних ефектів соціального неприйняття (Blackhart, Nelson, Knowles, Baumeister 2009; Cacioppo 2013; Gerber, Wheeler 2009; Hartgerink, Beest, Wicherts, Williams 2013). Як доводять праці багатьох дослідників (Saylor, Nida, Williams, Taylor, Smyth, Twyman), індивіди, які зазнають тривалого впливу остракізму в школах, переживають соціальний занепад та психологічні кризи протягом всього життя. Collins визначив школу як «наближення до цілого інституту», в якому життя характеризується частими взаємодіями, а Milner доводить, що остракізм здійснює суттєвий вплив на ієрархію статусу в освітніх установах. Більшість досліджень, що зосереджуються на жертвах у групі, використовують термін «знущання». Для того щоб дія була розглянута як знущання, вона повинна мати три ознаки: навмисне насильство, повторення, нерівні силові взаємини між агресором та жертвою ( Hymel, Olweus). Розрізняють чотири види знущань: фізичні, словесні, соціальні/реляційні знущання та кіберзалякування. Реляційне знущання визначається як акти поширення зловмисних чуток, виключення з соціальної діяльності та ін. (Hymel, Susan 2015).

Визначаючи спектр сучасних поглядів на вказане соціальне явище, його прояви у вигляді остракізованих тенденцій в середовищі освіти та його функціональне наповнення, поведінкові прояви, є потреба деталізувати деякі аспекти функцій соціального неприйняття в освітньому середовищі.

Мета статті - висвітлити функції остракізму в освітньому середовищі, ситуацію їх прояву в академічних групах.

Відповідно до мети, було сформульовано такі завдання:

1. Висвітлити основні функції остракізму в освітянському просторі;

2. Схарактеризувати вплив проходження етапів групоутворення на рівень прояву остракізаторських тенденцій в колективі;

3. Розкрити форми неприйняття індивіда до функціонального наповнення остракізації.

Виклад основного матеріалу дослідження. Williams (2007) визначає остракізм як «будьяку дію або акти ігнорування і виключення індивіда або групи окремою особою або групою». Вчений передбачає, що найбільш поширена форма остракізму в контексті сучасної освіти відмова від спілкування (р. 52 - 425). Соціальний біль може бути визначений як «тривожний досвід, що виникає в результаті сприйняття реальної або потенційної психологічної дистанції від близьких людей або соціальної групи. Дослідження вказують на те, що в підлітковий період «безмовне звернення» між соціально близькими індивідами - насмішка, виключення або ігнорування в освітянському просторі й інші пасивні або активні дії щодо відмови, незалежно від того, прийняті вони з добрих чи зловмисних намірів - $\epsilon$ потужним стимулятором соціального болю (Eisenberger 2003, p.290 - 292; Williams 2007, p.52 - 425). Особистість має потребу належати до групи, щоб вижити. Унаслідок цього кожен індивід має підвищені когнітивні здібності для вияву сигналів про відмову в соціальному прийнятті. Тож відмова з боку своєї академічної групи $\epsilon$ загрозливою ситуацією, що переживається як почуття особистої невпевненості. Відповідно до 
моделі загрози тимчасової потреби, остракізм може призвести до особистої і ситуативної невизначеності (Williams 2001, p.2 - 18).

Підлітки особливо сприйнятливі до наслідків остракізму: це період підвищення самосвідомості, коли особистість намагається ідентифікувати себе в середовищі й групі (Schneider 2006, p.351 - 365). Розглядаючи фактичні умови протікання процесу остракізації в освітньому середовищі, можна здійснити аналіз практичної сторони перебування індивідів в освітянському просторі й констатувати поділ його функцій на дві основні групи за характером дії:

- конструктивні - збереження сталого навчального середовища в ситуації остракізації деструктивно орієнтованих осіб.

- деструктивна - соціальне ігнорування суб'єктів освітнього середовища без зумовлених ознак (Milner, 2004).

За характером соціальної зумовленості виокремлюють соціально та персонально зумовлені функції. Соціально зумовлені - це функції, які стимулюють навчання окремих осіб нормам реагування, загальноприйнятих суспільством i, зокрема, їх однолітками, i які визначають поведінку дійових осіб у соціальній системі. Соціально зумовлені функції включають навколишнє середовище й особистий досвід у природі й вихованні індивіда (Mason, 2015). Серед таких функцій розрізняють:

1. Адаптаційна функція - забезпечує етап звикання. Це регулювання індивідуальної і групової поведінки, щоб відповідати створеній системі з норм і цінностей цього суспільства, класу або соціальної групи (Gerber 2009, p.468 - 488).

2. Захисна функція - забезпечує захист суб'єктивних відносин у середовищі групи. Пов’язана із запобіганням, управлінням і подоланням ситуацій, які негативно впливають на добробут людей. Соціальний захист складається з системи й програм, спрямованих на зниження рівня вразливості, зменшення схильності індивідів до ризиків (Яковлєв, 2006).

Персонально зумовлені - це функції, які стимулюють навчання окремих осіб в суспільстві, забезпечують вплив процесів соціалізації на ідентифікації особистості. Персонально зумовлені функції включають навколишній світ й індивідуальні особливості особистості (Mason, 2015). Серед таких функцій розрізняють:

1. Лідерська функція - контроль певними особами власних особистісних якостей лідера. Як наслідок - дії провідних учасників академічних груп для досягнення цілей, спрямовані впливати на поведінку учасників процесу, встановлювати чітке бачення організації, мотивації, скеровувати групу (Manges, 2017, p.21 - 29).

2. Ідентифікувальна функція - наслідок потреби підкріпити чи актуалізувати приналежність до групи. Це психологічна орієнтація особистості щодо когось чи чогось (наприклад, індивіда або групи), у результаті якої виникає почуття емоційної асоціації, значною мірою несвідомої. Ідеться про процес, за допомогою якого індивід моделює думки, почуття і дії після тих, що приписують об’єкту, який був включений як ментальний образ (Nida, 2009).

Освітнє середовище як окрему соціальну структуру та проходження в ній етапів особистісного становлення розглядають за загальноприйнятими науковими рамками становлення групи. Тукман розглянув близько п'ятдесяти досліджень групового розвитку й синтезував їх загальні риси в одній з найбільш часто цитованих моделей групового розвитку, що описує чотири лінійні стадії (формування, штурм, нормування та виконання), через які група пройде в своїй єдиній послідовності прийняття рішень.

Стадія 1: формування. Члени групи дізнаються одне про одного і про завдання існування групи. Індикатори цієї стадії можуть включати: неясні цілі, неуважність, непідтверджених членів, сум'яття, низький моральний дух, прихованість почуттів. Стратегія лідерства, яка допомагає новоутвореним групам, полягає в тому, щоб діяти як «координатор» (цілеспрямовано вибирати команду, сприяти груповим цілям і створювати загальну модель мислення команди) (Manges, 2017, p.21-29).

Стадія 2: штурм. Оскільки члени групи продовжують працювати, вони будуть залучати одне одного в суперечки про структуру групи, які характеризуються емоційними проявами й ілюструють боротьбу за статус у групі. Ці ознаки притаманні фазі штурму: відсутність 
згуртованості, суб’єктивність, приховані плани, конфлікти, конфронтація, образа, гнів, неузгодженість, невдачі. Стратегія лідерства, щоб допомогти групам, які штурмують, полягає в тому, щоб діяти в якості «тренера», допомагаючи «вирішувати конфлікти й напруженість» (тобто діяти як ресурс, розвивати взаємну довіру, заспокоювати освітнє середовище) (Manges, 2017, p. 21 $-29)$.

Стадія 3: нормування. Члени групи встановлюють неявні або явні правила про те, як вони досягнуть своєї мети. Вони стосуються типів спілкування, що є прийнятими або табуйованими для досягнення спільних завдань. Індикатори: досягнення, огляд, уточнення цілей, зміна/підтвердження ролей, виявлення ризикованих питань, впевненість у собі, активні дискусії, тестування нових позицій, виявлення сильних і слабких аспектів членів групи. Стратегія лідерства, щоб допомогти групам, які проходять стадію «нормування», полягає в тому, аби «успішно здійснювати і підтримувати проєкти» команди (передавати лідерство, шукати зворотний зв’язок від учасників, виділяти час для планування та залучення) (Gruter, 1986, p.149 - 395).

Стадія 4: виконання. Група приходить до висновку і реалізує рішення своєї проблеми. Показники: креативність, ініціативність, гнучкість, відкритість взаємин, гордість, турбота про індивідів, навчання, впевненість у собі, високий моральний дух, успіх.

Кожен 3 чотирьох етапів моделі «формування-штурм-нормування-виконання», запропонованої Tuckman, містить два аспекти: міжособистісні взаємини й норми. Gersick вказав на деякі більш пізні моделі, які відповідали аналогічним послідовним схемам соціального входження в групу. Зокрема йдеться про визначення групи, розвиток нових навичок в ії членів, розвиток i визначення відповідних групових ролей, генерація планів та ідей, погодження альтернатив сумісного існування, вирішення конфліктів, впровадження спільної діяльності й підтримка єдності (McGrath, 2004).

Уманський, розглядаючи свою концепцію поетапного розвитку групи, взяв за основу послідовну зміну стадій, які різняться ступенем психічної інтегрованості в діловій та емоційній сферах. Груповий розвиток, на його погляд, починається з точки, яка міститься всередині стадії й називається - конгломерат (сукупність незнайомих одне одному індивідів). Розвиток групи може відбуватися за двома напрямками. За просоціальною орієнтацією (рух до позитивного полюса) група, долаючи різні стадії, розвивається вгору, до найвищої точки, якою $є$ колектив. За асоціальною спрямованостю (рух до негативного полюса) група перетворюється на антиколектив. Поступальний розвиток групи, на думку Уманського, стримують (i зумовлюють) такі суперечності.

- між потенційними можливостями групи та її реальною діяльністю;

- між зростаючою інтеграцією членів групи і потребою кожного з них реалізуватися в ній особистісно;

- між посиленням організації групи на спільне «Ми» й усвідомленням місця й ролі групи в ширшій соціальній спільноті.

Підхід Уманського зосереджується на динаміці групових процесів, характеристиці диференційних ознак розвитку групи.

Woodcock, Francis, аналізуючи потребу зрілості групи, зосереджуються на таких стадіях іiі розвитку: притирання, ближній бій, експерементування, ефективність і зрілість. За їхнім спостереженням, із підвищенням якості роботи групи розширюються можливості об'єднання у ній індивідів. Унаслідок цього все більше їх бере участь у плануванні, прийнятті рішення і розв'язанні проблем (Manges, 2017, p. 21 - 29).

Різноманітні стадії групового розвитку аналізує стратометрична теорія колективу, емпірична модель розвитку групи та ін.

Попри певні відмінності, кожна модель утворення малих соціальних груп не залишає поза увагою такі основні етапи:

- орієнтування в ситуації. Особливість цього етапу полягає в формуванні чітких соціальних конструкцій у міжособистісних взаєминах;

- $\quad$ конфлікт. Він є результатом суперечності між індивідами, між групою та індивідами, а також між різними уявленнями про групові цілі й засоби їх досягнення; 
- динамічна рівновага. Забезпечує функціонування групи як єдиного цілого, не застраховуючи від виникнення нових непорозумінь (Hartgerink, 2014).

Розглядаючи концепції групоутворення, можна вказувати на те, що кожна група проходить етапи конфлікту, непорозумінь, неприйняття, відторгнення ідей і окремих членів групи в процесі становлення, що дає основу стверджувати: остракізація є невід'ємним елементом входження і становлення індивідів в освітньому середовищі (див. рис. 1.).

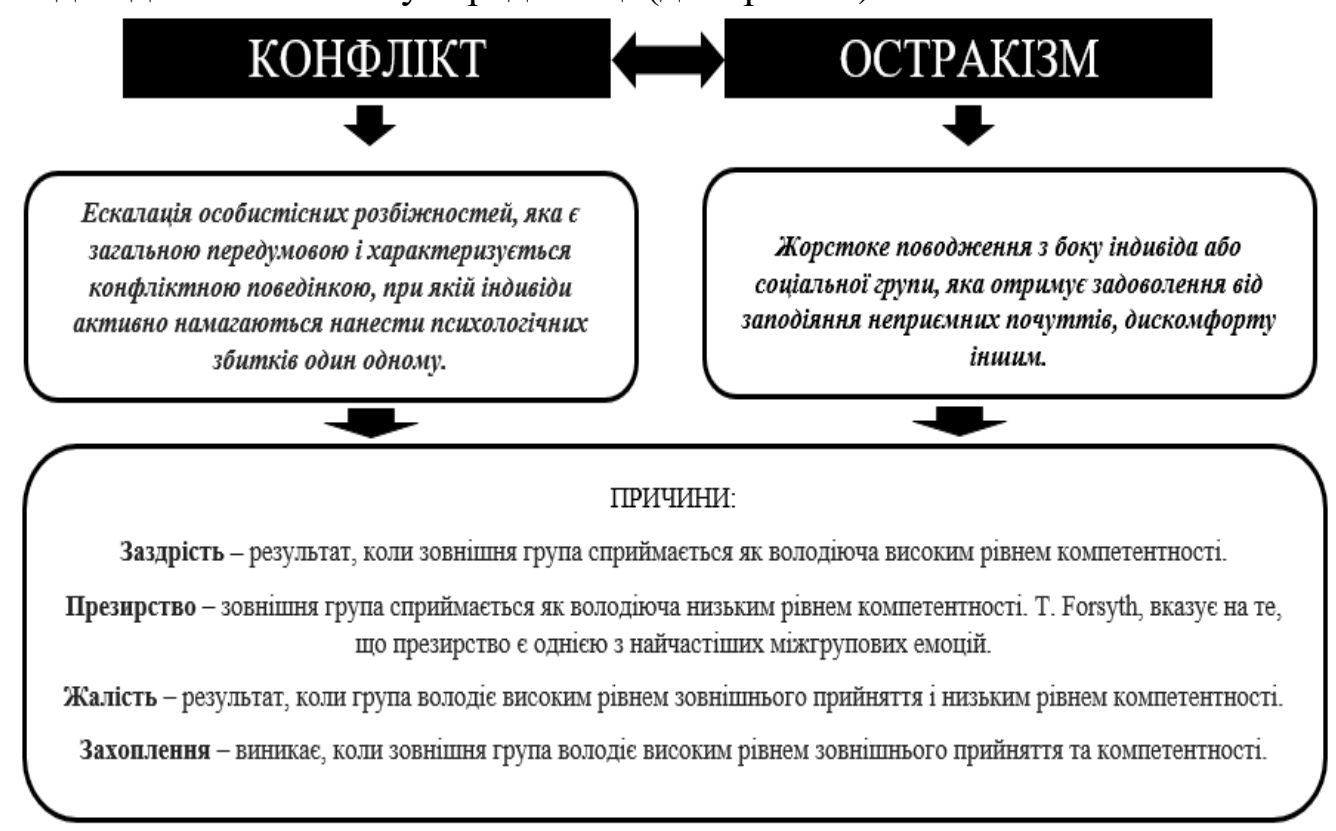

\section{Рис. 1. Стадія конфлікту в процесі групоутворення як прояв остракізму}

Соціальне виключення розуміють як часткове або повне вилучення індивідів із соціальної структури групи й суспільних процесів, створення умов, які не дають можливості цим індивідам відігравати значущу для них роль. Остракізація часто зумовлена такими психологічними механізмами особистості: заздрість, презирство, жалість, захоплення, які мають різний функціональний вплив на виключеного індивіда, але характеризуються однаковими наслідками неприйняття.

Такі характеристики функцій остракізації, як становлення соціально-групового середовища, доречно розглядати в комплексному контексті особливостей становлення академічних груп та особливостей вікового періоду індивідів. Dreeben вказує на те, що роль освітнього середовища - в підготовці дітей до належного функціонування як дорослих особистостей. Щоб ефективно брати участь в академічній групі, індивід має володіти достатнім рівнем соціалізації: мати нонконформіські нахили, приймати універсальні стандарти і функціонувати як повноцінний член групи (Gerber, 2009, p. 468 - 488). Leacock відмічає: навчання проходить в групах, а заохочення розподіляють на основі індивідуальних успіхів. Особи проходять процес входження в академічну й загальноосвітянську групу, володіючи різними здібностями й рівнем підготовки. Соціальні класові й етнічні відмінності в цінностях і мовних стилях можуть відображатися в поведінці й ставленні дітей до процесу навчання і міжособистісних взаємодій (Schneider, 2006, p. 351 - 365).

Подібні індивідуальні особливості учасників навчального процесу можуть впливати на формування остракізаторських нахилів в окремих особистостей або групи учасників, що, у свою чергу, спровокує виключення індивідів або поділ на мінігрупи в просторі академічної групи.

Оскільки рівень підготовки відображається практично у всіх групових процесах, таке раннє розшарування надає тривалий вплив на успішність і подальше ставлення індивіда до навчання та перебування в освітньому просторі. Групування в початкових класах та середній школі призводять до того, що діти ідентифікуються як переможці або переможені в навчанні (Сасіорро, 2013, p.2027). Інша точка зору підкреслює розподіл. Як вказали Bowles, Gintis, дитячий досвід сегрегації по групах або напрямках в освітньому середовищі з системою меритократичної винагороди може 
розподіляти їх, готуючи до сприйняття реальності дорослого світу, який характеризується ієрархічною сегментацією і нерівною винагородою. Результатом шкільної соціалізації, з цієї точки зору, $\epsilon$ рівень амбітності, направленості особистісного локус-контролю та продуктивності індивіда; нормативним результатом шкільної освіти, що є результатом процесу, який починається в початковій школі, є засвоєння меритократичного міфу (Hymel, 2015, p.293 - 299).

Вагомі соціально-емоційні поведінкові прояви індивідів шкільного віку прийнято поділяти на 4 вікових періоди (див. табл. 1.).

Таблиия 1.

\section{Соціально-емоційні особливості дітей икільного віку}

\begin{tabular}{|c|c|}
\hline $\begin{array}{c}\text { Віковий } \\
\text { період }\end{array}$ & Психологічні особливості \\
\hline $5-6$ років & $\begin{array}{ll}\text { - } & \text { прагне отримати похвалу дорослих; } \\
\text { - } & \text { насолоджується драматичною грою; } \\
\text { - } & \text { готовий брати участь в нових заходах/ пригодах під керівництвом } \\
& \text { дорослих; } \\
\text { - } & \text { готовий ідентифікувати себе зі старшими дітьми; } \\
\text { - } & \text { насолоджується вивченням нових матеріалів; } \\
\text { - } & \text { може бути легко наляканий новими або дивними подіями; } \\
\text { - } & \text { краще грає в невеликих групах; } \\
\text { - } & \text { вчиться співпрацювати з іншими, але іноді; } \\
\text { - } & \text { проявляється егоїстична поведінка. }\end{array}$ \\
\hline $7-9$ років & $\begin{array}{ll}\text { - } & \text { має сильне прагнення до незалежності; } \\
\text { - } & \text { розвинуте сильне почуття вірності друзям; } \\
\text { - } & \text { має необхідність належати до групи; } \\
\text { - } & \text { грає і товаришує з однолітками тієї ж статі; } \\
\text { - } & \text { подобається брати на себе відповідальність; } \\
\text { - } & \text { прагне жити в світі ігор, ритуалів і гумору; } \\
\text { - } & \text { прагне мати найкращого друга; } \\
\text { - } & \text { має чітке почуття добра і зла; } \\
\text { - } & \text { потрібна допомога в прийнятті однолітків, які відрізняються або } \\
& \text { вийшли з групи. }\end{array}$ \\
\hline $10-12$ років & $\begin{array}{ll}\text { - } & \text { насолоджується спілкуванням в невеликій групі однолітків; } \\
\text { - } & \text { подобається вступати в громадські групи; } \\
\text { - } & \text { прагне подорослішати; } \\
\text { - } & \text { дуже лояльно ставиться до групи однолітків; } \\
\text { - } & \text { формує близьку дружбу один на один; } \\
\text { - } & \text { зростає бажання захищати індивідуальність і незалежність; } \\
\text { - } & \text { може бути сміливим й конкурентоспроможним; } \\
\text { - } & \text { може об’єктивно критикувати однолітків і дорослих; } \\
\text { - } & \text { усвідомлює свої здібності. }\end{array}$ \\
\hline $13-14$ років & $\begin{array}{ll}\text { - } & \text { чутливий до своєї зовнішності; } \\
\text { - } & \text { створення особистого морального кодексу; } \\
\text { - } & \text { невпевненість у своєму місці в суспільстві; } \\
\text { - } & \text { залежність ідентичності від своєї академічної групи; } \\
\text { - } & \text { критика батьківських поглядів; } \\
\text { - } & \text { може характеризуватися крайністю і примхами в одязі, мові й }\end{array}$ \\
\hline
\end{tabular}




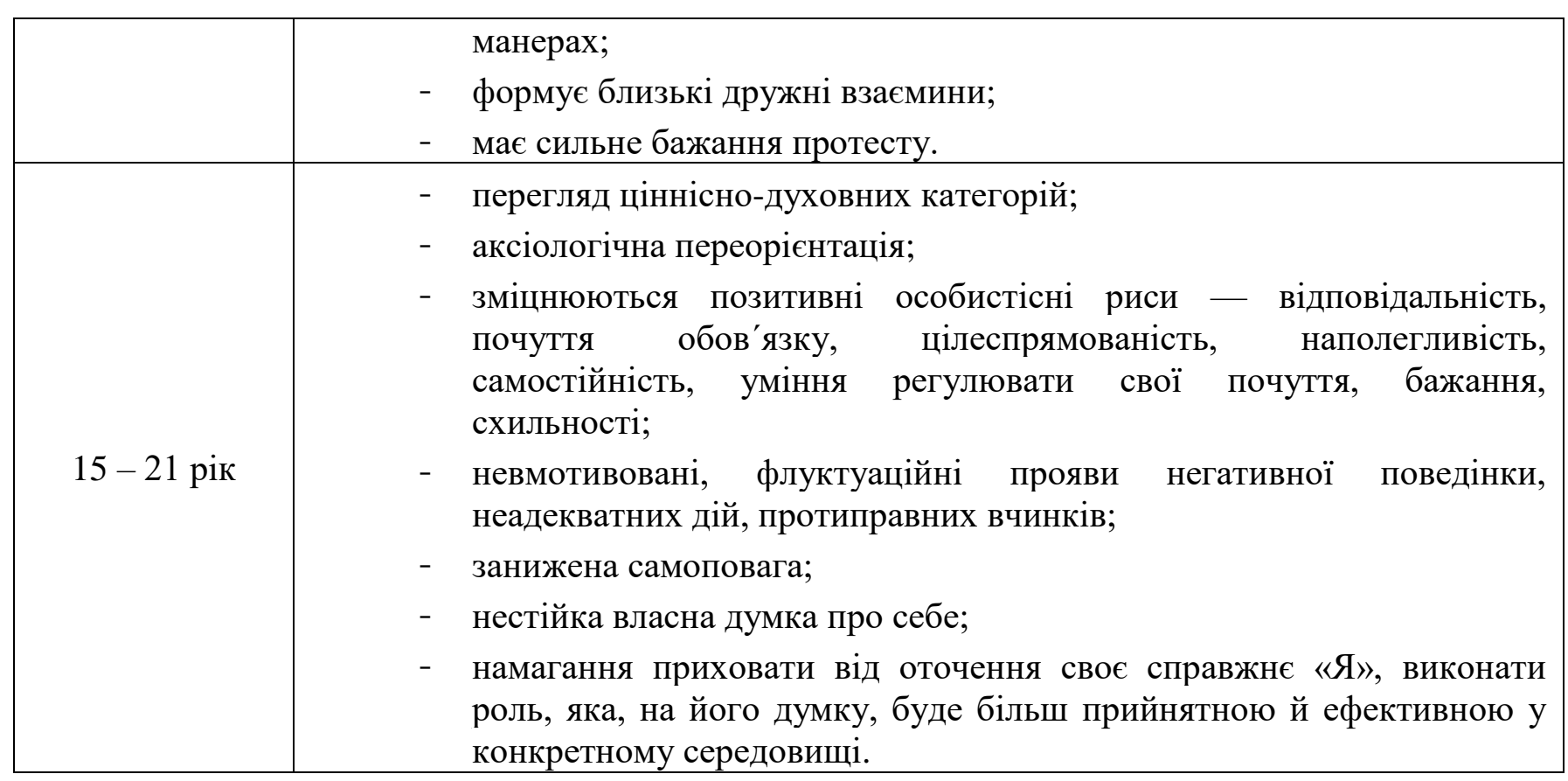

Остракізм - широко розповсюджене явище, яке є однією з найбільш недооцінених проблем безпеки в освітянському просторі. Вченими доведено: цькування відбуваються частіше в школі, ніж поза їі межами. А думку про те, що виключення індивіда $\epsilon$ певним ритуалом, який допомагає формувати характер учасників процесу, спростовано (Blackhart, 2009, p.269 - 309). Остракізм має довгострокові, шкідливі наслідки як для жертви, так і для остракізатора; натомість його часто помилково розглядають як вузький діапазон антигромадської поведінки, обмеженої дошкільними майданчиками початкової школи. Вивчення цього явища унеможливлює такий підхід до проблеми, відкриваючи причинно-наслідкові та функціональні аспекти феномена остракізму (Gruter 1986, p.149 - 395).

Відповідно до функціонального наповнення остракізації, виокремлюють такі форми неприйняття індивіда (див. табл. 2.).

Таблиия 2.

Прояви остракізму відповідно до функціонального впливу

\begin{tabular}{|c|c|c|}
\hline Форми & Функція та її характеристика & Прояви \\
\hline Інтолерантна & $\begin{array}{l}\text { Ксенофобічна }- \text { виключення із } \\
\text { соціального контакту під впливом } \\
\text { певних ознак, які маркують } \\
\text { особистість. }\end{array}$ & $\begin{array}{ll}\text { - } & \text { Мобінг; } \\
\text { - } & \text { Образи; } \\
\text { - } & \text { Гноблення; } \\
\text { - } & \text { Контроль або залякування. }\end{array}$ \\
\hline Інклюзивна & 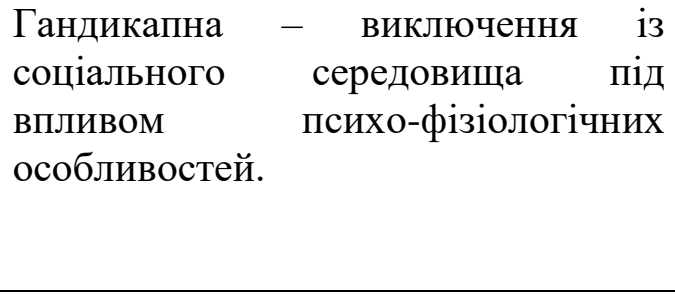 & $\begin{array}{l}\text { - Мобінг; } \\
\text { - Уникання; } \\
\text { - Насмішки; } \\
\text { - Потурання; } \\
\text { - Наклеп. }\end{array}$ \\
\hline Бойкотна & $\begin{array}{l}\text { Караюча }- \text { виключення із } \\
\text { соціального середовища як певна } \\
\text { форма покарання особистості за } \\
\text { вчинок чи дію. }\end{array}$ & $\begin{array}{l}\text { - } \text { Булінг; } \\
\text { - Кіберзалякування; } \\
\text { - } \text { Виключення; } \\
\text { - } \text { Ігнорування. }\end{array}$ \\
\hline
\end{tabular}




\begin{tabular}{|l|l|l|}
\hline Протестна & $\begin{array}{l}\text { Виключення або зміна ставлення як } \\
\text { форма протестного реагування на } \\
\text { входження в середовище. }\end{array}$ & - Антиманіфестації; \\
\hline
\end{tabular}

Говорячи про профілактику остракізації як функціонального наповнення становлення груп освітнього середовища, вказуємо на те, що відторгнення членів групи може бути більш шкідливим, ніж прояви булінгу й залякувань. Також остракізаторські тенденції представляють для науковців проблеми для розробки запобіжних засобів: остракізм з більшою вірогідністю не буде виявленим (Collins, 2008). Остракізатор уникне покарання, не зважаючи на намір завдати соціальних збитків суб’єкту, на якого буде спрямована дія. Остракізм немає конкретних, явних поведінкових проявів для попередження його впливів. А пряме втручання у формі примусу остракізатора до зупинки асоціальних проявів може бути контрпродуктивним (Eisenberger, 2003, 290 - 292). Відповідно, доречним буде докладання зусиль не на зміну поведінки остракіза, а на підтримку остракізованих індивідів з метою пом'якшення дії виключення.

Висновки і перспективи подальших розвідок. Теоретичний аналіз аспектів функцій остракізму в освітніх установах дозволив обгрунтувати поняття «остракізму», яке використовується для позначення будь-якої дії або акта ігнорування і виключення індивіда або групи окремою особою чи групою. Аналізуючи теоретичні відомісті, що висвітлюють цю проблему, досліджено, що в підлітковий період «безмовне звернення» між соціально близькими індивідами $є$ потужним стимулятором соціального болю. Остракізм є особливим випадком заподіяння «соціального болю» і входить в категорію відносного залякування або серйозного залякування у взаєминах. Залякування, зі свого боку, є особливим випадком насильства характеризується повторенням і асиметричними владними відносинами.

На основі узагальнення стану розроблення проблеми показано, що підлітки та діти молодшого шкільного віку особливо сприйнятливі до наслідків остракізму: це період підвищення самосвідомості, коли особистість намагається ідентифікувати себе в середовищі й групі. Констатовано поділ функцій цього явища в середовищі освіти на дві основні групи за характером дії: конструктивні (збереження сталого навчального середовища в ситуації остракізації деструктивно орієнтованих осіб), деструктивні (соціальне ігнорування суб'єктів освітнього середовища без зумовлених ознак). Підтверджено важливість розгляду проходження етапів особистісного становлення в межах освітнього простору як окремої соціальної групи за загальноприйнятими науковими рамками становлення групи. Визначено, що цей процес має надавати можливість проходження окремих етапів і навичок індивідуалізації: визначення групи, розвиток нових навичок у її членів, розвиток і визначення відповідних групових ролей, генерація планів і ідей, погодження альтернатив сумісного існування, вирішення конфліктів, впровадження спільної діяльності й підтримка єдності.

Здійснено аналіз теоретичних знань про перебіг процесів у сучасному просторі освіти й виявлено, що кожна модель утворення малих соціальних груп не залишає поза увагою такі основні етапи:

- орієнтування в ситуації. Особливість цього етапу полягає в ідентифікації з іншими учасниками міжособистісних взаємин;

- конфлікт. Він $є$ результатом суперечності між індивідами, між групою та індивідами, а також між різними уявленнями про групові цілі й засоби їх досягнення;

- динамічна рівновага. Забезпечує функціонування групи як єдиного цілого, не застраховуючи від виникнення нових непорозумінь

Виявлено, що освітні установи є середовищем остракізації, цей процес $є$ невід'ємним елементом входження і становлення індивідів в освітньому середовищі. Подальший розгляд цієї проблеми вбачаємо в більш розгорнутому вивченні основних функціональних впливів, що виникають при загрозі приналежності, неоднозначності, невизначеності ситуацій і відмови у взаєминах; дослідженні взаємозалежності остракізації та індивідуальних процесів проходження становлення в освітянській групі.

Випуск 14, 2020 Збірник наукових праць РДГУ. 


\section{СПИСОК ПОСИЛАНЬ}

Яковлев, А. М. (2006). Преступность и соичильная психология. Москва.

Blackhart, G. C., Nelson, B. C., Knowles, M. L., \& Baumeister, R. F. (2009). Rejection elicits emotional reactions but neither causes immediate distress nor lowers self-esteem: A meta-analytic review of 192 studies on social exclusion. Personality and Social Psychology Review, 13, 269-309.

Cacioppo, S., Frum, C., Asp, E., Weiss, R., Lewis, J., \& Cacioppo, J. (2013). A quantitative meta-analysis of functional imaging studies of social rejection. Scientific Reports, 3, 2027.

Collins, P. A. (2008). Micro-Sociological Theory. Princeton University Press.

Eisenberger, N. I., Lieberman, M. D., \& Williams, K. D. (2013). Does rejection hurt? An fMRI study of social exclusion. Science, 302, 290-292.

Gerber, J., \& Wheeler, L. (2009). On being rejected: A meta-analysis of experimental research on rejection. Perspectives on Psychological Science, 4, 468-488.

McGrath, J. E., \& Tschan, F. (2004). Temporal matters in social psychology: Examining the role of time in the lives of groups and individuals. Washington: American Psychological Association.

Gruter, M., \& Masters, R. D. (1986). Ostracism: A social and biological phenomenon. Ethology and Sociobiology, 7, 149-395.

Hartgerink, C., Beest, I., Wicherts, J., \& Williams, K. (2014). Ordinal effects of ostracism: A metaanalysis of Cyberball studies. Unpublished Manuscript, Tilburg University.

Hymel, S., \& Susan, M. (2015). Four Decades of Research on School Bullying: An Introduction. American Psychologist, 70, 293-299.

Manges, C., Scott-Cawiezell, J., \& Marcia, M. (2017). Maximizing Team Performance: The Critical Role of the Nurse Leader. Nursing Forum, 52, 21-29.

Mason, H. (2015). Trajan. Encyclopcedia Britannica.

Milner, M. (2004). Freaks, Geeks and Cool Kids. Teenagers in an Era of Consumerism, Standardized Tests, and Social Media. Routledge.

Nida, S., Twyman, K., Saylor, C., \& Williams, K. (2009). Ostracism, depression, and adjustment in children and adolescents. Paper presented at the annual meeting of the Midwestern Psychological Association.

Schneider, M., \& Somers, M. (2006). Organizations as complex adaptive systems: Implications of complexity theory for leadership research. The Leadership Quarterly, 17, 351-365.

Williams, K. (2007). Ostracism. Annual Review of Psychology, 58, 425-52.

Williams, K. (2001). Ostracism: The Power of Silence. New York: Guilford Press.

\section{REFERENCES}

Yakovelev, A. M. (2006). Prestupnost' $i$ sotsialnaya psikhologiya [Crime and Social Psychology]. Moskva. [in Russian].

Blackhart, G. C., Nelson, B. C., Knowles, M. L., \& Baumeister, R. F. (2009). Rejection elicits emotional reactions but neither causes immediate distress nor lowers self-esteem: A meta-analytic review of 192 studies on social exclusion. Personality and Social Psychology Review, 13, 269-309. [in English].

Cacioppo, S., Frum, C., Asp, E., Weiss, R., Lewis, J., \& Cacioppo, J. (2013). A quantitative meta-analysis of functional imaging studies of social rejection. Scientific Reports, 3, 2027. [in English].

Collins, P. A. (2008). Micro-Sociological Theory. Princeton University Press. [in English].

Eisenberger, N. I., Lieberman, M. D., \& Williams, K. D. (2013). Does rejection hurt? An fMRI study of social exclusion. Science, 302, 290-292. [in English].

Gerber, J., \& Wheeler, L. (2009). On being rejected: A meta-analysis of experimental research on rejection. Perspectives on Psychological Science, 4, 468-488. [in English].

McGrath, J. E., \& Tschan, F. (2004). Temporal matters in social psychology: Examining the role of time in the lives of groups and individuals. Washington: American Psychological Association. [in English].

Gruter, M., \& Masters, R. D. (1986). Ostracism: A social and biological phenomenon. Ethology and Sociobiology, 7, 149-395. [in English]. 
Hartgerink, C., Beest, I., Wicherts, J., \& Williams, K. (2014). Ordinal effects of ostracism: A metaanalysis of Cyberball studies. Unpublished Manuscript, Tilburg University. [in English].

Hymel, S., \& Susan, M. (2015). Four Decades of Research on School Bullying: An Introduction. American Psychologist, 70, 293-299. [in English].

Manges, C., Scott-Cawiezell, J., \& Marcia, M. (2017) Maximizing Team Performance: The Critical Role of the Nurse Leader. Nursing Forum, 52, 21-29. [in English].

Mason, H. (2015). Trajan. Encyclopcedia Britannica. [in English].

Milner, M. (2004). Freaks, Geeks and Cool Kids. Teenagers in an Era of Consumerism, Standardized Tests, and Social Media. Routledge. [in English].

Nida, S., Twyman, K., Saylor, C., \& Williams, K. (2009). Ostracism, depression, and adjustment in children and adolescents. Paper presented at the annual meeting of the Midwestern Psychological Association. [in English].

Schneider, M., \& Somers, M. (2006). Organizations as complex adaptive systems: Implications of complexity theory for leadership research. The Leadership Quarterly, 17, 351-365. [in English].

Williams, K. (2007). Ostracism. Annual Review of Psychology, 58, 425-52. [in English].

Williams, K. (2001). Ostracism: The Power of Silence. New York: Guilford Press. [in English].

\section{FUNCTIONS OF OSTRACISM IN THE EDUCATION SYSTEM}

Victoria Nazarevich,

Candidate of Psychological Sciences, Associate Professor Department of Developmental and Educational Psychology

Rivne State University of the Humanities http://orcid.org/0000-0002-0111-7070

DOI https://doi.org/10.35619/prap_rv.vi14.167

Abstract. In the article, the author tries to reveal the features of the ostracism functions within the system of conditions of modern education and systematize the socio-psychological manifestations of the social exclusion of individuals or groups. Particular attention is paid to the analysis of the system of the phenomenon functional content, its manifestations in the educational space, the impact on the personality that lack of attention and recognition has. People who are ostracized in educational institutions for a long time demonstrate a low level of mental health.

The article is devoted to the analysis factors of the main stages of the formation of the group and individual's entry into the academic education system. It is indicated that a person needs belonging to a group in order to survive. As a result, each individual has increased cognitive abilities for the manifestation of denial of social acceptance signals. Thus, the rejection or alertness of the group is a threatening situation, which is perceived as a feeling of personal insecurity and leads to ostracization of the individual. The actual conditions of ostracization in the educational environment are highlighted, the practical side of individuals stay in the educational space is analyzed, and the division of ostracization functions into two main groups by the nature of the action is established.

The role of considering the passage of personal development stages within the academic group is indicated, according to the generally accepted scientific framework for the formation of the group, which can be characterized by: determining the boundaries of the group, developing new skills among its members, developing and defining appropriate group roles, generating plans and ideas, coordinating coexistence alternatives, conflict resolution, implementation of joint activities and support for unity. Conclusions are drawn in the system of ostracism functions in the educational space that each group goes through the stages of conflict, misunderstanding, rejection of ideas and individual members of the group in the process of formation, which gives the basis to assert that ostracization is an integral element of the entry and formation of individuals in the educational environment. Further consideration of this problem is seen in a more detailed study of the main functional influences arising from the threat of belonging, ambiguity, uncertainty of situations and failure in relationships; the study of the interdependence between ostracization and individual processes of formation in the educational group.

Key words: ostracism, social rejection, the functionality of ostracism, the educational system, group formation, conflict.

Стаття надійшла до редакиії 29.01.2020 p

Випуск 14, 2020 Збірник наукових праць РДГУ. 